\title{
Challenges and opportunities for quality seed potato availability and production in Uganda
}

\author{
A.R. Aheisibwe, A. Barekye, P. Namugga and A.A. Byarugaba \\ Kachwekano Zonal Agricultural Research and Development Institute, P. O. Box 421, Kabale, Uganda
}

Author for correspondence: ambaheisibwe@gmail.com

\begin{abstract}
Potato yields in Uganda have remained low at $7.5 \mathrm{t} \mathrm{ha}^{-1}$. This low yield is attributed to low yielding varieties, poor management practices and lack of quality seed potatoes among other factors. This study was conducted to ascertain the challenges and opportunities of quality seed potato availability and production in the southwestern highlands agro-ecological zone (SWHAEZ). A total of 15 farmer groups were randomly selected from a sample size of 200 farmers and individually interviewed. The results of study indicated that high transaction costs $(43.5 \%)$, lack of clear seed delivery system $(\mathbf{4 0 . 5 \%})$ and limited information on the source of seed $(14.0 \%)$ were the main constraints limiting farmers' access to and use of quality seed potato. Up to $93 \%$ of the farmers in SWHAEZ use home saved seed from previous harvests and conventional ware potato markets, whose quality is not guaranteed. Although over $70 \%$ of the farmers were convinced that quality of seed had a positive effect on yield increase, $72 \%$ of them still use poor quality seed often infected by bacterial wilt. In addition, $52 \%$ of the farmers lacked specific storage facilities for potato seed; and this further lowered the grade of the seed quality. However, a number of opportunities existed for production and access to quality seed including; various proven technologies for producing quality seed potato and ready demand for potato seed and ware potato. Of the seed potato production technologies, positive selected seed (PSS) seemed to have the highest quantity of seed; while basic seed produced heaviest tubers than the rest of the technologies.
\end{abstract}

Key words: Quality seed potato, seed system and challenges

\section{Introduction}

Potato (Solanum tuberosum L.) is a crop of major economic importance worldwide (FAO, 2008). In terms of global production, it is the third most important food crop after rice and wheat for human consumption and over a billion of people on earth feed on potatoes (CIP, 2014; Haverkort and Struik, 2015). Global potato production is estimated at $20.8 \mathrm{tha}^{-1}$, and potato yield vary considerably across regions. Generally, Asia and Europe are the world's major potato producing 
regions, accounting for more than $80 \%$; while Africa is the least, accounting for about 5\% (FAOSTAT, 2013). Nationally, potato yields in Uganda have remained low at $7.5 \mathrm{t} \mathrm{ha}^{-1}$ compared to other countries in which case, $40-60 \mathrm{t} \mathrm{ha}^{-1}$ are achievable (FAO, 2013). The low yields are attributed to poor quality seed among other factors (Byarugaba et al., 2013).

The potential demand for seed potatoes in Uganda is estimated at 239,328 tonnes and seed availability is only $0.13 \%$ of potential demand (KAZARDI, 2014). The demand for potato seed has been increasing due to the great interest that farmers have in potato farming and emergency of processing factories within the region. Lack of quality seed has encouraged potato farmers to resort to planting home saved tubers from previous harvests or sourced from markets and neighbours (Muthoni et al., 2011). Such tubers are often of poor health status due to latent infections by the bacterial wilt (Rastonia solanacearum), viruses and other tuber-borne pathogens (Kinyua et al., 2011).

Emerging initiatives and technologies have been used to address the challenge of unavailability of certified and quality declared seed potato in the Eastern and Central Africa (ECA) region, which include seed plots techniques, positive seed selection, and production of minitubers (Kinyua et al., 2011). However, these require additional supportive policies for recognition and regulation of seed production and distribution in the potato value chain. The initiatives on seed potato quality improvement have not been fully effective, due to institutional limitations of the actors along the seed potato value chain.

In Uganda, the potato formal seed system is not well developed, it operates through a semi-formal institutional arrangement for multiplication and distribution of quality declared seed potato. This study was conducted to identify constraints limiting farmers' access to and use of quality seed potato, as well as identify potential opportunities existing within the seed system for quality seed potato multiplication, availability and delivery.

\section{Materials and methods}

A survey was conducted in four districts mainly Kabale, Kisoro, Rukungiri and Kanungi in SWHAEZ in Uganda focused on potato production technology, seed source and availability constraints, method of seed acquisition and delivery. Purposive sampling was used to select eight subcounties from four districts. A sample of 200 potato farmers were interviewed using a structured questionnaire. Simple random sampling method was later used to select 15 groups out of the 41 from the targeted sub-counties from which a total of 10 participants and at least 3 non participants were randomly selected.

Additionally, secondary data from Kachwekano Zonal Agricultural Research and Development Institute (KAZARDI) on-farm experiments and reports were utilised to supplement the primary data. Data collected was subjected to analysis of variance (ANOVA) and means separated using the least significant difference (LSD).

\section{Results and discussion}

\section{Constraints limiting availability and production of quality seed potatoes}

There is limited access to quality declared seed, with over $90 \%$ of farmers in the zone using low quality seed, resulting from 
home saved-seed recycled from previous seasons and conventional ware potato market (Table 1). This is attributed to high transaction costs, limited information on source of seed, lack of flush out seed systems, inadequate seed production and distribution system. Recycled seed has high infection of seed-borne disease, especially bacterial wilt and viruses (Table 1). Majority (93\%) of farmers still rely on informal sources of seed potato, despite the fact that the quality of seed from such sources is not guaranteed. These findings are closely similar to those of Kinyua $e t$ al. (2011) in Kenya, who found out that more than $95 \%$ of seed potato is sourced from farmers' own harvests or markets or neighbours. This has an implication on the productivity at farm level and could be the main factor as to why potato yields have remained low in the zone.

The study showed that the majority of farmers $(72 \%)$ (Table 1) believed that seed quality contributes to increased yields; while $17 \%$ were indifferent about the effect of category of seed on potato yields. Only $12 \%$ felt that category of seed did not have effect on yields. The finding that most of the farmers were convinced that seed quality positively influenced yields, and yet majority of them use seed whose quality was not guaranteed, indicates existence of various constraints that bar farmers from accessing and using quality seed.

The study also indicated that average quantities of seed per hectare used in the previous season were very low among the survey households, falling short of the recommended rates by a very big margin of 3, 000 to $35,00 \mathrm{~kg}$ per hectare (TNAU, 2013). The average seed rate used by farmers was $830.69 \mathrm{~kg} \mathrm{ha}^{-1}$ at an average price of $0.31 \$$ which is less by $25.6 \%$ of the recommended rate (TNAU, 2013).
This is largely attributed to the high cost associated with access to quality seed, which finally limits the production of ware potatoes (Muthoni and Nyamongo, 2009). There was a high variability in usage of seed among the districts, with Kisoro and Kabale district using more of the quality seed compared to Rukungiri and Kanungu (Table 2). The low amounts of seed and price in Rukungiri and Kanungu could be attributed to the low importance that potato holds in the farming system of the district as compared to the other two districts where it is highly rated both as a staple crop and source of income. In addition, the low amounts of seed per hectare used in the respective districts could also be attributed to the size of the tubers used by most farmers that tend to be very small $(<30 \mathrm{~mm})$ compared to medium sized ones which are recommended.

The study findings revealed that farmers had limited storage facilities hence affecting the quality of available seed; with $52 \%$ of the farmers storing seed potato in conventional stores with seed potato was mixed with other produce (Table 3). This is attributed to limited awareness and knowledge on good postharvest management practices when managing saved seed. Such poor seed storage practices lead to low yields of the ensuing crop (CIP, 2011)

The dormancy period for the varieties grown by farmers varied across the districts, in the decreasing order of Kisoro, Kabale, Kanungu and Rukungiri (Table 3). This is attributed to differences in temperatures and altitude across these districts. Kanungu and Rukungiri have relatively warmer conditions compared to Kabale and Kisoro districts (Temperature data not shown). This is likely to affect the planting time as seed from the warmer 


\begin{tabular}{|c|c|c|c|c|c|}
\hline Variable & Kabale & Kisoro & Kanungu & Rukungiri & Mean $\%$ \\
\hline \multicolumn{6}{|l|}{ Percentage of farmers limited by various factors to access quality seed potato } \\
\hline High transaction costs & 36.0 & 48.0 & 41.4 & 63.9 & 43.5 \\
\hline Lack of clear seed delivery system & 45.0 & 32.0 & 38.9 & 32.1 & 40.5 \\
\hline Limited information on source & 15.3 & 12.0 & 19.4 & 3.6 & 14.0 \\
\hline \multicolumn{6}{|l|}{ Percentage of farmers accessing seed from various sources for planting } \\
\hline Conventional ware potato market & 51.4 & 36.0 & 52.8 & 75.0 & 53.0 \\
\hline Previous harvest & 42.3 & 68.0 & 36.1 & 7.1 & 39.5 \\
\hline Government institution seed producer (KAZARDI) & 9.9 & 12.0 & 8.3 & 3.6 & 9.0 \\
\hline Private seed producer (UNSPPA) & 7.2 & 0.0 & 13.9 & 7.1 & 7.5 \\
\hline Group seed plot & 10.8 & 0.0 & 0.0 & 0.0 & 6.0 \\
\hline Fellow Farmer & 1.8 & 0.0 & 2.8 & 17.9 & 4.5 \\
\hline Own seed plot & 0.9 & 0.0 & 0.0 & 0.0 & 0.5 \\
\hline \multicolumn{6}{|l|}{ Farmers' knowledge on whether "seed quality contributes to increased potato yields". } \\
\hline Percentage of farmers in agreement that quality seed leads to increased yield & 75.6 & 80 & 61.1 & 64.3 & 72 \\
\hline Percentage of farmers not sure on whether quality seed leads to increased yield & 9.9 & 20 & 22.2 & 32.1 & 16.5 \\
\hline Percentage of farmers not agreeing that quality seed leads to increased yield & 14.4 & 0 & 16.6 & 3.6 & 11.5 \\
\hline Sample size & 111 & 25 & 36 & 28 & 200 \\
\hline
\end{tabular}


Table 2. Quantity and price of seed potato utilized by farmers in potato production for 2012B season

\begin{tabular}{lrrrrr}
\hline Input & Kabale & Kisoro & Kanungu & Rukungiri & Mean \\
\hline Seed rate $\left(\mathrm{kg} \mathrm{ha}^{-1}\right.$ ) & 780.33 & 1268.86 & 649.09 & 624.48 & 830.69 \\
Price of seed potato (US\$ per kg) & 0.33 & 0.37 & 0.28 & 0.24 & 0.31 \\
\hline
\end{tabular}

Exchange rate: $1 \$=3400 \mathrm{UGX}$

Table 3. Storage constraints to seed potato production in south-western Uganda

\begin{tabular}{|c|c|c|c|c|c|}
\hline Storage facilities & Kabale & Kisoro & Kanungu & Rukungiri & Mean \\
\hline \multicolumn{6}{|c|}{$\begin{array}{l}\% \text { of farmers using different storage facilities and dormancy period for potatoes across the } \\
\text { districts }\end{array}$} \\
\hline $\begin{array}{l}\text { Stored in a normal store mixed with } \\
\text { other produce }\end{array}$ & 42.3 & 60.0 & 63.9 & 67.9 & 52.0 \\
\hline Covering with dry grass & 9.9 & 16.0 & 5.6 & 0.0 & 8.5 \\
\hline Diffused lights store & 9.0 & 4.0 & 8.3 & 7.1 & 8.0 \\
\hline Dormancy period (days) & 77.19 & 106.2 & 59.81 & 45.54 & 73.4 \\
\hline
\end{tabular}

areas tend to sprout faster than the seed stored in the cooler areas. The long dormancy period in most cases forces farmers to plant unsprouted seed that leads to delayed emergency and subsequently reduced productivity especially when the tuber initiation and bulking phase of the crop coincide with the dry season.

In view of this, interventions to either reduce the cost of certified seed or improve quality seed potato production and, hence, returns to farmers are critical if use of certified seed is to be enhanced. The initiatives include but not limited to improvement of own seed supply through positive selection, seed plots, use of aeroponic technology and proper seed storage management.

\section{Seed plot technology}

This approach utilises the principle of maximising tuber production per unit area and disease-free land through high-density planting in seed plots. The opportunity with seed-plot technique is that it provides a platform through intensive management practices against bacterial wilt and other tuber-borne diseases. According to Kinyua et al. (2011), this technology can achieve 2.5 to 3 times higher land productivity for bacterial wilt-free seed potato, translating into a $50 \%$ less land requirement to meet on-farm seed tuber needs than the case under conventional ware production systems. This leads to more land being available for rotation in preparation for the establishment of seedplots, to provide seed for subsequent 
planting. Although this technology has been tested under a wide range of production circumstances, the results are similar to earlier findings by Kinyua et al. (2001a, b). This is evidence that once the technology is popularised and utilised, shortage of clean planting material may reduce.

Additionally, farmers greatly appreciate the seed-plot technology because it does not demand purchase of new seed every season, thus it reduces the cost of production.

\section{Positive seed selection}

Positive seed selection approach uses the principle of selecting the best plants in a ware field as mother plants to provide seed for the following season. This methodology was developed by CIP to train potato farmers in development of their own quality seed potato farmers to bridge the huge gap of insufficient certified seed (Gildermacher, 2011). The approach is credited for increasing potato yields to at least 30\% higher than farmers practice, where farmers obtain seed potato from ware plantings with no regard to the health status of the mother plants (SchulteGeldermann, 2012).

The benefits of positive seed selection are in terms of reduced disease incidences of bacterial wilt (BW) and viruses and increased productivity. Evidence from KAZARDI experiments indicate that Positive Selected Seed (PSS) yields more than Farmer Selected Seed (FSS); while yields between PSS and basic seed (BS) are not significantly different (Fig. 2). However, the different seed types showed a similar trend in tuber weight, with BS being higher than PSS, which was in turn higher than FSS.

As indicated in Figure 2, improved yields can be realised from positive selected seed and basic seed compared with farmers' practices under ideal conditions. Such seed results in high quality of tubers, making them attractive for use as seed. This implies that if done well, the positive selected seed and seed plot technologies can significantly improve the quality of home-saved seed for smallholder farmers.

Results in Table 4 indicate that about $45 \%$ of all the farmers involved in the study

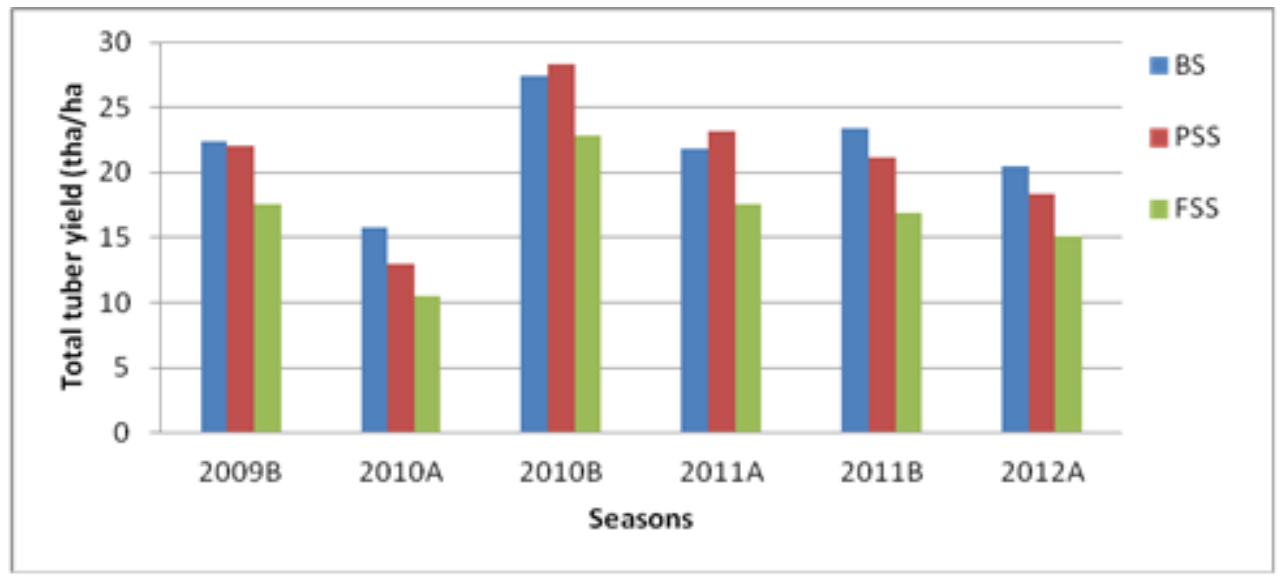

Figure 1. Potato yield gains from basic seed, positive selected seed and farmer selected seed for six seasons at 51 sites in Kabale and Kanungu districts in Uganda. BS = Basic Seed PSS $=$ Positive Selected Seed FSS $=$ Farmer Selected Seed. 


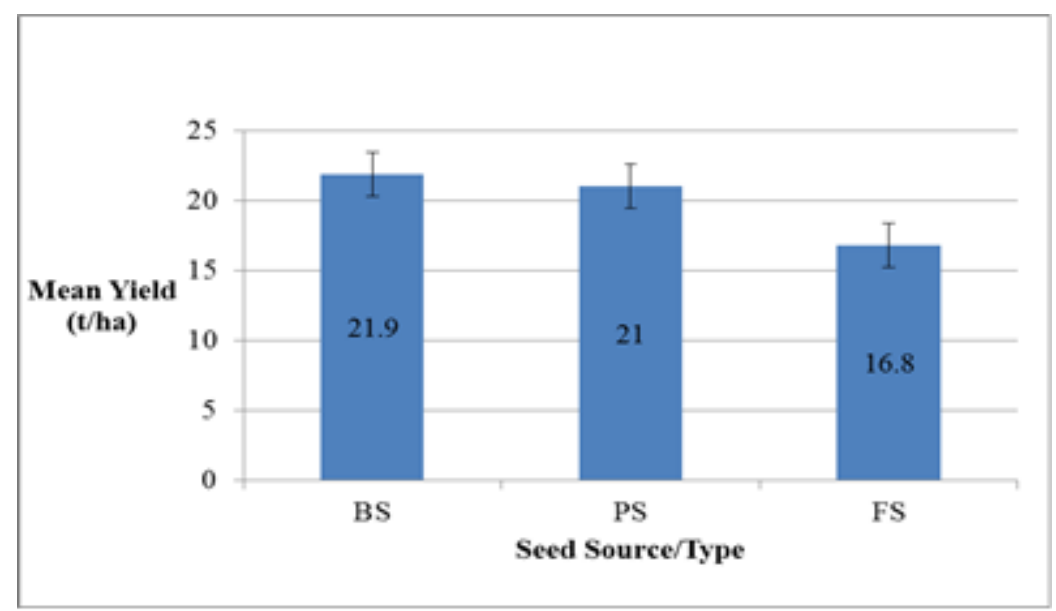

Figure 2. Potato yield for three seed types across six seasons in Kabale and Kanungu districts in Uganda.

were aware of seed plot technology. Kabale district had a higher proportion of farmers $(59.5 \%)$ compared to the other three districts. Existence of more farmers in Kabale who are aware of seed plot technology can be attributed to the intensive efforts by KAZARDI and Uganda National Seed Potato Producers Association (UNSPPA) and other agencies which have been engaged in the promotion of seed plot technology in all the districts. More male farmers (48\%) than female farmers $(29 \%)$ were aware of the seed plot technology and this could be attributed to two issues; firstly because potato production is a male dominated and secondly more males than females have access to information through attending trainings, meetings and other sources. These findings generally indicate that awareness on seed plot production is still wanting.

On the other hand, Table 4 further indicate that about $44 \%$ of all the farmers involved in the study were aware of positive selection. Kabale district had more farmers aware of positive selection (69.4\%) compared to their counter parts in Kanungu, Kisoro and Rukungiri in the decreasing order. More male headed households $(46 \%)$ than female headed households (35\%) were aware of positive seed selection. Comparing the proportions of farmers who had ever practiced positive seed selection and those who are currently practicing the technology, it is evident that there was a reduction.

The three major reasons given by farmers for not adopting positive seed selection technology included; no knowledge about positive selection technology reported by $52.5 \%$, lack of adequate information and advisory support by $29 \%$ and difficulties in identifying healthy plants by $17 \%$.

\section{Seed production through aeroponics}

Aeroponics technology is a method of growing crops in nutrient medium. The growing of potato plants in aeroponics system is considered as safe and ecologically friendly for producing natural, healthy plants and crops. This technology has advantages over the other systems or techniques, including conventional seed potato production, hydroponics and plant 
Table 4. Results on awareness and establishment of seed potato production technology for quality seed enhancement in Kabale, Kisoro, Kanungu and Rukungiri-Uganda

\begin{tabular}{|c|c|c|c|c|c|c|c|}
\hline Variable & Kabale & Kisoro & Kanungu & Rukungiri & $\begin{array}{c}\text { Male } \\
\text { headed }\end{array}$ & $\begin{array}{l}\text { Female } \\
\text { headed }\end{array}$ & Mean \\
\hline Proportion $(\%)$ of farmers who are aware about seed plot & 59.5 & 24.0 & 27.8 & 25.0 & 47.6 & 29.4 & 44.5 \\
\hline $\begin{array}{l}\text { Proportion }(\%) \text { of farmers who are aware of positive seed } \\
\text { selection technology }\end{array}$ & 69.4 & 4.0 & 25.0 & 3.6 & 45.8 & 35.3 & 44.0 \\
\hline Sample size & 111 & 25 & 36 & 28 & 166 & 34 & 200 \\
\hline $\begin{array}{l}\text { Proportion }(\%) \text { of farmers who have ever established a } \\
\text { seed plot }\end{array}$ & 37.8 & 16.0 & 16.7 & 0.0 & 28.9 & 11.8 & 26.0 \\
\hline $\begin{array}{l}\text { Proportion }(\%) \text { of farmers who are currently practicing } \\
\text { seed plot under individual and group plots }\end{array}$ & 36.9 & 16.0 & 13.9 & 0.0 & 27.7 & 11.8 & 25.0 \\
\hline $\begin{array}{l}\text { Proportion }(\%) \text { of farmers who have ever practiced } \\
\text { positive seed selection }\end{array}$ & 56.8 & 0.0 & 13.9 & 0.0 & 35.5 & 26.5 & 34.0 \\
\hline $\begin{array}{l}\text { Proportion }(\%) \text { of farmers currently practicing positive } \\
\text { seed selection }\end{array}$ & 54.1 & 0.0 & 11.1 & 0.0 & 33.7 & 23.5 & 32.0 \\
\hline
\end{tabular}

\section{Percentage of the farmers limited by various factors to adopt positive seed selection technology}

No knowledge about positive selection technology

Lack of adequate information and advisory support

\begin{tabular}{rrrrrrr}
44.2 & 80.0 & 69.4 & 78.6 & 48.8 & 70.6 & 52.5 \\
33.8 & 19.2 & 16.9 & 20.4 & 29.6 & 25.9 & 29.0 \\
16.8 & 0.2 & 13.1 & 0.0 & 10.2 & 2.5 & 17.0 \\
111 & 25 & 36 & 28 & 166 & 34 & 200 \\
\hline
\end{tabular}

Sample size 
Table 5. Annual mini-tuber production in soil substrate in 2007-2009 and aeroponics 20092010 at KAZARDI in Kabale, Uganda

\begin{tabular}{|c|c|c|c|}
\hline \multirow[t]{2}{*}{ Variety } & \multicolumn{3}{|c|}{ Number of mini-tubers } \\
\hline & Soil substrate* & Aeroponics ${ }^{* *}$ & $\begin{array}{l}\text { Aeroponics to soil } \\
\text { productivity ratio }\end{array}$ \\
\hline Rutuku & 1,247 & 6,653 & 5.3 \\
\hline Kachpot1 & 875 & 45,493 & 52.0 \\
\hline Victoria & 8,862 & 40,774 & 4.6 \\
\hline Total & 10,983 & 92,920 & 8.5 \\
\hline
\end{tabular}

*and ** are average mini-tuber production of three years on $100 \mathrm{~m}^{2}$ in soil substrate and one year production on $70 \mathrm{~m}^{2}$ in aeroponic boxes, respectively

tissue culture. The system is ten times more successful than conventional techniques, tissue culture and hydroponics, which take longer and are more labour intensive (CIP, 2008).

Ritter et al. (2001) demonstrated that aeroponics minituber production under temperate weather conditions can substantially improve yields. However, according to Otazu (2010), aeroponic technology can achieve multiplication rates of 1:100. In addition, harvesting minitubers in aeroponic systems is convenient, clean and permits a greater size control through sequential harvesting (Ritter et al., 2001).

Evidence from KAZARDI experiments indicate that the aeroponics technology is more efficient and effective in terms of increasing the number of minitubers per plantlet, with the number of minitubers increasing to more than eight compared with the conventional one for subsequent generation of pre-basic and basic seed (Table 5). This technology therefore has the potential to improve the supply of good and healthy seed potato hence increased potato productivity.

\section{Conclusion}

We conclude that high transaction costs, lack of a clear seed delivery systems and imperfect information on source of seed limit accessibility to quality seed. Additionally, emerging initiatives and proven technologies such as mini-tuber production and quality-declared seed require additional supportive policies for recognition and streamlining their production and distribution.

Despite the challenges, the review found out that there exists a number opportunities for production and access to quality seed production. The seed-plot technique and positive seed selection, both of which were introduced and later validated should be scaled up to address the seed potato quality and supply side constraints among potato farmers.

Linkages to existing systems for generating mini-tubers such as aeroponics systems and certified/clean seed establishments should be strengthened while utilising seed quality assurance practices and postharvest management of 
seed potato for enhanced quality seed potato and productivity.

\section{References}

Byarugaba, A.A., Namugga, P. and Imelda, N.K. 2013. Identification of potato clones of population $\mathrm{B} 3 \mathrm{C} 2$ with durable field resistance to late blight (Phytophthora infestans) and high yields in Uganda. African Journal of Agricultural Research 8(23):30553059.

CIP (International Potato Center). 2011. Roadmap for investment in the seed potato value chain in eastern Africa. Lima, Peru. 27 pp.

CIP (International Potato Center). 2014. Available at http://cipotato.org/potato (accessed on 29 January 2014).

FAO (Food and Agriculture Organization of the United Nations), 2008. International year of the potato. Available at http://www.potato 2008.org (accessed on 15 March 2013). FAO, Rome, Italy.

FAOSTAT. 2013. Food and Agriculture Organization statistical database, United Nations, Rome, Italy. Available online. URL: http://www.faostat3 fao.org/home/index.html.

Gildermacher, P., Demo, P., Kinyae, P., Wakahiu, M., Nyongesa, M. and Zchocke, T. 2011. "Select the best" Positive selection to improve farmers saved seed potatoes." Trainers Manual, CIP, Lima, Peru.

Haverkot, A.J., Struik, and P.C. 2015. Yield levels of potato crops: Recent achievements and future prospects. Field Crops Research 182:76-85.

Kinyua, Z.M., Smith, J.J., Oduor, G.I. and Wachira, J.N. 2001a. Increasing the availability of disease-free potato tubers to small-hold farmers in Kenya.
Proceedings of the Seventh Symposium of the International Society for Tropical Root CropsAfrica Branch; 12-16 October, 1998; pp. 494-499. Cotonou, Republic of Benin.

Kinyua, Z.M., Smith. J. J., Lung'aho, C., Olanya, M. and Priou., S. 2001b. On farm successes and challenges of producing bacterial wilt-free tubers in seed plots in Kenya. African Crop Science Journal 9(1):279-285.

Kinyua, M., Bararyenya, A., SchutteGeldermann, E., Obura, B.O., Kashaija, I.N., Tindimubona, S., Opio, F., Oyena, D., Rwomushana, I., Muriithi, W.M., Kinoti, J., Namugga, P., Kimoone, G., Inamahoro, M., Niko, N. and Ndayihanzamaso, P. 2011. Overcoming seed potato quality constraints to tackle food security and poverty in East and Central Africa in the $21^{\text {st }}$ Century. ASARECA Abstracts.

Muthoni, J. and Nyamongo, D.O. 2009. A review of constraints to ware Irish potatoes production in Kenya. Journal of Horticulture and Forestry 1(7):098-102.

Muthoni, J., Mbiyu, M and Kabira, J.N. 2011. Up-scaling production of certified potato seed tubers in Kenya: Potential of Aeroponics Technology. A Journal of Horticulture and Forestry 3(8):238-243.

Otazú, V. 2010. Manual on quality seed potato production using aeroponics. International Potato Center (CIP), Lima, Peru. 44 pp.

Raemaekers, R.H. (ed.). 2001. Crop production in tropical Africa. Directorate General for International Co-operation (DGIC), Brussels, Belgium. 1540pp. 
Ritter, E., Angulo, B., Riga, P., Herran, C., Relloso, J. and San, J.M. 2001. Comparison of hydroponics and aeroponics cultivation systems for the production of potato minitubers. Potato Research 44:127-135.

Schulte-Geldermann, E., Gildemacher, P.R. and Struik, P.C. 2012. Improving seed health and seed performance by positive selection in three Kenyan potato varieties. American Journal of Potato Research 89(6):429-437.

TNAU AGRITECH PORTAL, 2013. http://agritech.tnau.ac.in/horticulture/ horti vegetables potato.html Accessed on 9 September 2013. 